\title{
(JIPD)
}

Jurnal Inovasi Pendidikan Dasar

Vol. 4, No. 2, Bulan Juli Tahun 2020, Hal. 86-90

E-ISSN: 2598-408X, P-ISSN: 2541-0202

http://unikastpaulus.ac.id/jurnal/index.php/jipd

https://doi.org/10.36928/jipd.v4i2.606

\section{EFEKTIVITAS PEMBELAJARAN PKN TERHADAP PENGEMBANGAN SIKAP NASIONALISME SISWA DI KABUPATEN MANGGARAI}

\author{
Yohanes Wendelinus Dasor \\ Prodi PGSD Universitas Katolik Indonesia Santu Paulus Ruteng \\ Fakultas Keguruan dan Ilmu Pendidikan, Prodi PGSD \\ J1. Jend.Ahmad Yani, No.10, Ruteng, 86508 \\ email: wendidasor@gmail.com
}

Diterima: 11 Januari 2020, Direvisi: 15 Mei 2020, Diterbitkan: 15 Juli 2020

\begin{abstract}
The purpose of this study was to determine the extent of the effectiveness of PKN learning towards the development of student nationalism in Manggarai Regency. By knowing the effectiveness of PKN learning, the government and educational institutions should specifically pay attention to the whole process of organizing learning. This type of research used in this research is descriptive qualitative conducted in schools from elementary school to high school in Manggarai Regency, East Nusa Tenggara. Data collection techniques in this study were observation and questionnaire. Data analysis techniques include the analysis of student responses and activities. Based on the results of research students in Manggarai Regency have an attitude of nationalism known thanks to the learning PKN obtained during their education. The spirit of student nationalism is reflected in the attitude of creating harmony in religious life, upholding the law, being active in national development and feeling proud as an Indonesian citizen.
\end{abstract}

Keywords: Effectiveness, Nationalism, PKN, Learning, Students

\begin{abstract}
Abstrak: Tujuan dari penelitian ini adalah untuk mengetahui sejauhmana efektivitas pembelajaran PKN terhadap pengembangan sikap nasionalisme siswa di Kabupaten Manggarai. Dengan mengetahui efektivtas pembelajaran PKN maka seiogianya pemerintah dan lembaga pendidikan untuk secara khusus memberi perhatian pada seluruh proses penyelenggaraan pembelajaran. Jenis Penelitian yang digunakan dalam penelitian ini adalah deskriptif kualitatif yang dilaksanakan di sekolah-sekolah dari jenjang Sekolah Dasar hingga Sekolah Menengah Atas di Kabupaten Manggarai, Nusa Tenggara Timur. Teknik pengumpulan data dalam penelitian ini adalah observasi dan angket. Teknik analisis data mencakup analisis respon dan aktivitas siswa. Berdasarkan hasil penelitian siswa di Kabupaten Manggarai memiliki sikap nasionalisme diketahui berkat pembelajaran PKN yang diperloleh selama menempuh pendidikan. Semangat nasionalisme siswa tersebut tercermin dalam sikap menciptakan kerukunan dalam hidup beragama, menjunjung tinggi hukum, aktif dalam pembangunan nasional dan perasaan bangga sebagai warga negara Indonesia.
\end{abstract}

Kata Kunci: Efektivitas, Nasionalisme, PKN, Pembelajaran, Siswa

\section{PENDAHULUAN}

Indonesia merupakan negara kesatuan yang berbentuk republik. Dikatakan sebagai negara kesatuan, karena bangsa Indonesia terdiri dari berbagai macam suku, ras, adat istiadat, kebudayaan dan agama. Walaupun demikian keanekragaman tersebut bernaung dalam negara kesatuan Republik Indonesia. Untuk tetap mempertahankan dan menjaga keutuhan negara yang majemuk atau beragam tersebut dibutuhkan warga negara yang memiliki kesadaran dan pemahaman akan sikap dan semangat nasionalisme atau kebangsaan. Dan salah satu cara untuk meningkatkan pemahaman dan kesadaran akan rasa nasionalisme tersebut adalah melalui pendidikan. 
Pendidikan merupakan suatu investasi jangka panjang dalam menamkan rasa semangat nasionalisme warga negara disamping untuk membebaskan diri dari kebodohan dan keterbelakangan. Melalui pendidikan yang berbekal semangat nasionalisme, warga negara selalu tetap mempertahankan keanekaragaman dalam bingkai NKRI. Untuk itu penelitian ini untuk mengetahui sejauhmana efektivitas pembelajaran PKN khususnya materi nasionalisme dalam pengembangan sikap nasionalisme siswa. Melalui hasil penelitian ini sekiranya menjadi bahan masukkan bagi lembaga pendidikan dan pemerintah untuk mengevaluasi hasil pendidikan yang berwawasan dan berkesadaran akan rasa kebangsaan atau nasionalisme.

Pendidikan kewarganegaraan merupakan pendidikan yang berlandaskan pada nilai-nilai pancasila guna mewariskan dan melestarikan nilai-nilai moral pancasila yang berakar pada budaya bangsa Indonesia. Sebagaimana yang dikatakan oleh Susanto (2013: 224) pendidikan kewarganegaraan merupakan mata pelajaran yang dipakai sebagai wahana dan wadah untuk melestarikan dan mengembangkan nilai moral dan luhur yang berakar pada budaya bangsa Indonesia.

Dalam UU Sisdiknas No.20 Tahun 2003

Bab 1 Pasal 1 bahwa pendidikan adalah usaha sadar dan terencana untuk mewujudkan suasana belajar dan proses pembelajaran agar peserta didik secara aktif mengembangkan potensi dirinya untuk memiliki kekuatan spiritual keagamaan, pengendalian diri, kepribadian, kecerdasan, akhlak mulia serta keterampilan yang diperlukan dirinya ,masyarakat, dan negara. Berdasarkan point dalam undang-undang tersebut matapelajaran PKN merupakan mata pelajaran yang memfokuskan pada pembentukan pengetahuan dan sikap terhadap pribadi dan perilaku peserta didik.

PKN merupakan matapelajaran yang diberikan disekolah sejak tahun 1957 dengan nama Kewarganegaraan atau Civics . Muatan isi matapelajaran Kewarganegaraan pada saat itu adalah sebatas tentang hak dan kewajiban warga negara, serta cara-cara memperoleh kewarganegaraan bagi yang kehilangan status kewarganegaraan.

Dalam perkembangan selanjutnya nama matapelajaran PKN selalu mengalami perubahan. Pada kurikulum tahun 1986 sejak munculnya Orde Baru mata pelajaran Civics berubah nama menjadi Kewargaan Negara. Pada kurikulum tahun 1975 berdasarkan amanat Ketetapan MPR No. IV/MPR/1973, mata pelajaran ini berubah nama menjadi Pendidikan Moral Pancasila (PMP). PMP berubah nama lagi pada kurikulum 1984 maupun Kurikulum 1994 menjadi PPKN (Pendidikan Pancasila dan Kewarganegaraan).

Sejak bergulirnya era reformasi tahun 1998 mata pelajaran PPKN dianggap sebagai salah satu biang keladi kediktatoran pada Zaman Orde Baru. PPKN dianggap sebagai salah satu alat oleh pemerintah Orde Baru untuk mengindoktrinasi warga negara guna melanggengkan kekuasaan presiden. Sehingga pada era reformasi matapelajaran PPKN turut juga mengalami proses reformasi ke arah pendidikan kewarganegaraan dengan paradigma baru. Pendidikan Kewarganegaraan paradigma baru berorientasi pada terbentuknya masyarakat sipil (sivil society) yang mampu berperan serta secara aktif dalam sistem pemerintahan negara yang demokratis. Sebagaimana dalam Print et al (1999:25) civic education is necessary for the building and consolidation of a democratic society.

Pendidikan

kewarganegaraan berparadigma baru tersebut disertai juga dengan perubahan nama PPKN menjadi PKN sejak lahirnya kurikulim berbasis kompetensi tahun 2004 yang selanjutnya diganti menjadi kurikulum KTSP tahun 2006. Matapelajaran PKN pada KBK khusus ditingkat sekolah dasar diintegrasikan pada matapelajaran IPS, sehingga menjadi PKPS (Pendidikan Kewarganegaraan dan Pengetahuan sosial). Akan tetapi pada tingkat menengah (SMP dan SMA) tetap merupakan matapelajaran sendiri. Akan tetapi pada kurikulum KTSP 2006 kemudian PKN menjadi matapelajaran yang berdiri sendiri pada semua jenjang baik sekolah dasar maupun pada pendidikan menengah.

Pada kurikulum 2013 PKN berubah nama lagi menjadi PPKN. Perubahan nama ini dengan maksud agar PPKN tetap kembali mengedepankan nilai-nilai moral pancasila yang adalah sebagai fundamen keutuhan Negara Kesatuan Republik Indonesia yang beranekaragam dari segi budaya, agama, suku, adat istiadat, ras dan sebagainya.

Pendidikan Pancasila dan Kewarganegaraan (PPKN) mengandung muatan isi yang beragam. Salah satunya adalah materi tentang nasionalisme. Di sekolah dasar seturut kurikulum 2013 materi nasionalisme tidak diberikan secara tersirat apa yang dimaksudkan dengan nasionalisme. Akan tetapi semangant 
nasionalisme tersebut ditanamkan melalui beragam materi diantaranya: makna bersatu dalam keberagaman dilingkungan sekitar, keberagaman umat beragama dimasyarakat, bentuk keberagaman suku bangsa, sosial dan budaya di Indonesia yang terikat persatuan dan kesatuan, manfaat persatuan dan kesatuan untuk membangun kerukunan hidup dan beberapa materi lainnya. Demikian juga untuk untuk kurikulum pendidikan menengah, bahwa materi nasionalisme tidak tersurat dalam nama materinya akan tetapi tersirat dalam beragam materi yang ada.

Materi nasionalisme tidak secara tegas diberikan pada nama materi yang dimaksud mengingat luas dan dalamnya makna nasionalisme tersebut. Untuk memahami nasionalisme sendiri kita juga harus memahami apa yang dimaksudkan dengan bangsa. Bangsa adalah suatu asas spiritual, suatu jiwa. Bangsa adalah suatu kesatuan solidaritas yang besar, terbentuk oleh perasaan yang timbul akibat pengorbanan-pengorbanan yang telah dibuat bersama dimasa lalu dan yang dalam masa depan bersedia dibuat suatu komitmen bersama lagi. Dalam Wikipedia bangsa adalah suatu kelompok manusia yang dianggap memiliki semangat nasionalisme, memiliki identitas bersama, adanya kesamaan bahasa, ideologi, budaya, sejarah dan tujuan yang sama serta umumya memiliki asal usul keturunan yang sama. Dengan demikian bahwa nasionalisme adalah rasa kebangsaan

Nasionalisme adalah pandangan yang berpusat pada bangsanya atau semacam etnosentrisme. Etnosentrisme merupakan sikap atau pandangan yang berpangkal pada masyarakat dan kebuadayaan sendiri yang disertai dengan sikap meremehkan masyarakat dan kebudayaan lain. Akan tetapi berbeda dengan etnosentrisme, nasionalisme lebih mengutamakan sikap menghormati dan menghargai bangsa lain. Hal tersebut sebagai yang dikatakan oleh Sunarso dkk (2008 : 36) bahwa nasionalisme adalah sikap nasional untuk mempertahankan dan mengisi kemerdekaan dan harga diri Bangsa sendiri dan sekaligus menghormati bangsa lain.

Dalam Kamus Besar Bahasa Indonesia (1996 : 684) nasionalisme adalah paham atau ajaran untuk mencintai bangsa dan negara sendiri. Atau dengan kata lain nasionalisme adalah kesadaran keanggotaan dalam suatu bangsa yang secara aktual dan potensial bersama-sama mencapai, mempertahankan dan yang memiliki identitas, integritas untuk mencapai kemakmuran dan kekuatan bangsa dalam semangat kebangsaan. Sedangkan L Stoddard (dalam Djaja, 2009 :14) juga menyatakan bahwa nasionalisme merupakan suatu kepercayaan atau keyakinan yang dimiliki oleh sebagian besar individu untuk menyatakan rasa kebangsaan secara bersama dalam suatu bangsa.

Dengan demikian bahwa nasionalisme dipahami dalam dua pengertian yaitu dalam arti sempit dan luas. Dalam arti sempit nasionalisme merupakan sikap mengagung-agungkan bangsa sendiri disertai sikap merendahkan keberadaan bangsa-bangsa lain. Sedangkan dalam arti luas nasionalisme merupakan sikap mempertahankan dan mengagung-agung bangsa sendiri disertai adanya sikap hormat terhadap bangsa lain. Nasionalisme dalam arti ini dapat mengekpresikan sikap menjaga persatuan dan kesatuan ditengah pluralitas kehidupan berbangsa dan bernegara.

Nasionalisme dalam konteks Indonesia mengalami dinamika sepanjang sejarah. Pada zaman penjajahan nasionalisme berhubungan dengan upaya memperebutkan kemerdekaan dari para penjajah. Sedangkan pada awal-awal kemerdekaan hingga Orde Baru, nasionalisme berkaitan dengan upaya mempertahankan dan mengisi kemerdekaan. Akan tetapi permasalahan sekarang adalah apakah semangat nasionalisme yang dulu lahir sebagai akibat adanya rasa sepenasip dan sepenanggungan tetap menggelora hingga saat ini?

Permasalahan bangsa saat ini adalah merosotnya penghayatan akan nilai-nilai nasionalisme dalam diri anak-anak bangsa. Munculnya radikalisme menunjukkan bahwa situasi bangsa saat ini sedang mengalami krisis rasa kebangsaan. Adanya tindak kekerasan terhadap etnis tertentu yang dibalut dengan gerakan separatis semakin mempertajam hipotesis akan merosotnya sikap nasionalisme yang diwariskan secara turun temurun dari para founding fathers. Untuk itu perlu adanya gebrakan secara besar-besaran dalam upaya meningkatkan kembali semangat nasionalisme warga negara. Salah satu upaya yang telah dilakukan selama ini adalah melalui pendidikan, lebih kusus dengan hadirnya matapelajaran PKN. Akan tetapi pertanyaannya adalah sejauh mana efektivitas pembelajaran PKN terhadap perkembangan sikap nasionalisme siswa. Penelitian ini adalah sebagai upaya menjawab efektivitas pembelajaran PKN tersebut 
khususnya bagi siswa sekolah dasar di Kabupaten Manggarai Nusa Tenggara Timur.

\section{METODE}

Jenis Penelitian yang digunakan dalam penelitian ini adalah deskriptif kualitatif yang dilaksanakan di sekolah-sekolah dari jenjang Sekolah Dasar hingga Sekolah Menengah Atas di Kabupaten Manggarai, Nusa Tenggara Timur. Tujuan utama dari penelitian ini adalah untuk mendeskripsikan hasil analisis efektivitas pembelajaran PKN terhadap pengembangan sikap nasionalisme siswa. Karena itu yang menjadi subyek utama penelitian ini adalah para siswa dari jenjang SD hingga SMA yang berjumlah 100 orang dengan perincian 33 siswa dari tingkat SD dan SMP serta 34 siswa dari tingkat SMA.

Teknik pengumpulan data dalam penelitian ini adalah observasi dan angket. Observasi adalah untuk mendapatkan data-data sikap nasionalisme dalam keseharian siswa baik di sekolah maupun dalam masyarakat. Sedangkan angket adalah instrumen utama dalam penelitian ini untuk mendapatkan data-data tentang efektivitas pembelajaran PKN terhadap pengembangan sikap nasionalisme siswa. Teknik analisis data mencakup analisis respon dan aktivitas siswa.

Analisis respon siswa dengan menggunakan rumus:

Sikap Nasionalisme Siswa $=\frac{\mathrm{A}}{\mathrm{B}}$ X $100 \%$

Keterangan:

$\mathrm{A}=$ Rata-rata frekuensi setiap kategori

$\mathrm{B}=$ Rata-rata nilai maksimum setiap kategoti

\section{HASIL PENELITIAN DAN PEMBAHASAN}

Berikut adalah temuan dan analis data terkait efektivitas pembelajaran PKN terhadap pengembangan sikap nasionalisme siswa:

\section{Menciptakan Kerukunan Umat Beragama}

Pembelajaran PKN dalam kurikulum pendidikan juga dimaksudkan untuk menghasilkan siswa yang memiliki sikap menjaga kerukunan umat beragama. Berdasarkan hasil penelitian siswa di Kabupaten Manggarai mampu menjaga kerukunan dalam kehidupan beragama berkat materi yang diberikan guru melalui matapelajaran PKN. Berikut adalah respon siswa terkait sikap nasionalisme siswa

Tabel 1. Hasil Resposn Siswa

\begin{tabular}{|c|c|c|}
\hline Pilihan & Frekuensi & $\begin{array}{c}\text { Persentasi } \\
(\%)\end{array}$ \\
\hline Selalu & 91 & $91 \%$ \\
\hline Kadang-Kadang & 9 & $9 \%$ \\
\hline Jarang & - & \\
\hline Tidak Pernah & - & \\
\hline \multicolumn{2}{|c|}{ Total } & $100 \%$ \\
\hline \multicolumn{2}{|c|}{ Berdasarkan tabel di atas mayoritas }
\end{tabular}

siswa yaitu $91 \%$ selalu menciptakan kerukunan dalam kehidupan beragama. Kemudian $9 \%$ yang kadang-kadang menciptakan kerukunan dalam kehidupan beragama.

Kerukunan dalam hidup umat beragama pada siswa di Kabupaten Manggarai nyata dalam perilaku menghormati umat beragama lain yang sedang beribadah, ikut serta menjaga ketertiban dan keamanan pada saat umat beragama lain merayakan hari-hari besar kegamaan, memberi ucapan pada saat hari raya keagamaan dan sedapat mungkin menghadiri undangan mengikuti upacara keagamaan.

\section{Menjunjung Tinggi Hukum}

Sikap menjunjung tinggi hukum adalah ketaatan siswa terhadap segala jenis peraturan yang berlaku dalam kehidupan berbangsa dan bernegara. Berdasarkan hasil penelitian siswa di Kabupaten Manggarai memiliki sikap menjunjung tinggi hukum yang tinggi. Berikut adalah hasil respon siswa terhadap sikap menjunjung tinggi hukum di Kabupaten Manggarai.

Tabel 2. Sikap Menjunjung Tinggi Hukum

\begin{tabular}{|c|c|c|}
\hline Pilihan & Frekuensi & $\begin{array}{c}\text { Persentasi } \\
(\%)\end{array}$ \\
\hline Selalu & 81 & $81 \%$ \\
\hline Kadang-Kadang & 10 & $10 \%$ \\
\hline Jarang & 9 & $9 \%$ \\
\hline Tidak Pernah & - & \\
\hline Total & & $100 \%$ \\
\hline
\end{tabular}

Dari tabel terbut di atas $81 \%$ siswa selalu menjunjung tinggi hukum dalam berprilaku di tengah masyarakat, $10 \%$ yang menunjukkan sikap kadang-kadang dan $9 \%$ yang jarang menunjukkan sikap menjunjung tinggi hukum dalam masyarakat. Beberapa indikator prilaku siswa yang menjunjung tinggi hukum di Kabupaten Manggarai antara lain dilihat dari ketaatan di jalan raya, ketaatan pada peraturan yang berlaku di sekolah misalnya kedisiplinan, tidak menyontek, dan sebagainya, ketaatan hukum dalam hidup bermasyarakat misalnya menjaga ketertiban dan keamanan dalam hidup bermasyarakat. 


\section{Aktif dalam Pembangunan Nasional}

Pembangunan nasional merupakan segala upaya untuk meningkatkan berbagai aspek kehidupan manusia dalam suatu sistem ketatanegaraan. Pembangunan nasional melingkupi segala bidang kehidupan yang mencakup sosial, politik, hukum, keamanan, pendidikan dan kebudayaan dan sebagainya. Siswa di Kabupaten Manggarai turut serta dalam pembangunan nasionalnya. Hal tersebut dapat dilihat pada tabel berikut:

Tabel 3

\begin{tabular}{|c|c|c|}
\hline Pilihan & Frekuensi & $\begin{array}{c}\text { Persentasi } \\
(\%)\end{array}$ \\
\hline Selalu & 59 & $59 \%$ \\
\hline Kadang-Kadang & 30 & $30 \%$ \\
\hline Jarang & 11 & $11 \%$ \\
\hline Tidak Pernah & - & \\
\hline Total & & $100 \%$ \\
\hline
\end{tabular}

Berdasarkan tabel tersebut di atas sebnyak $59 \%$ siswa yang selalu aktif dalam pembangunan nasional, $30 \%$ siswa kadangkadang ikut serta dalam pembangunan nasionalnya. Sedangkan $11 \%$ siswa yang jarang turut serta dalam pembangunan nasionalnya. Sikap ikut serta dalam pembangunan nasional siswa di Kabupaten Manggarai tercermin dalam sikap ikut serta dalam kegiatan bakti sosial, selalu menjunjung tinggi musyawarah untuk mufakat, ikut serta mencerdaskan kehidupan berbangsa dan bernegara melalui ikut serta dalam proses pendidikan, menjaga dan memelihara memfasilitas umum.

\section{Bangga sebagai Warga Negara Indonesia}

Bangga sebagai warga negara indonesia sebagai salah satu bentuk sikap nasionalisme adalah tercermin dalam sikap suka memakai produk dalam negeri, menjaga nama baik bangsa, ikut menjaga persatuan dan kesatuan. Di samping itu bangga sebagai warga negara tidak serta merta menganggap remeh bangsa lain, egoisme, ekstrimisme dan primordialisme. Siswa di Kabupaten Manggarai berdasarkan hasil penelitian $77 \%$ selalu bangga sebagai warga negara ndonesia, $13 \%$ kadang-kadang bangga sebagai warga negara dan $10 \%$ jarang bangga sebagai warIga negara. Untuk lebih jelasnya dapat dilihat pada tabel berikut:

\begin{tabular}{|c|c|c|}
\hline \multicolumn{3}{|c}{ Tabel 4 } \\
\hline Pilihan & Frekuensi & $\begin{array}{c}\text { Persentasi } \\
(\%)\end{array}$ \\
\hline Selalu & 77 & $77 \%$ \\
\hline Kadang-Kadang & 13 & $13 \%$ \\
\hline
\end{tabular}

\begin{tabular}{|c|c|c|}
\hline Jarang & 10 & $10 \%$ \\
\hline Tidak Pernah & - & \\
\hline Total & & $100 \%$ \\
\hline
\end{tabular}

\section{KESIMPULAN}

Nasionalisme merupakan pandangan yang berpusat pada bangsanya sendiri atau semacam etnosentris. Sikap nasionalisme setiap individu tidak terlepas dari proses pendidikan yang didapatnya dalam lembaga pendidikan. Siswa di Kabupaten Manggarai memiliki sikap nasionalisme diketahui berkat pembelajaran PKN yang diperloleh selama menempuh pendidikan. Semangat nasionalisme siswa tersebut tercermin dalam sikap menciptakan kerukunan dalam hidup beragama, menjunjung tinggi hukum, aktif dalam pembangunan nasional dan perasaan bangga sebagai warga negara Indonesia.

\section{DAFTAR RUJUKAN}

Djaja, W.2009. Pancasila di antara Ideologi Besar Dunia. Klaten: Cempaka Putih

Kamus Besar Bahasa Indonesia.1996. Edisi Kedua: Balai Pustaka

Print et al (1999:25) civic education is necessary for the building and consolidation of $a$ democratic society.

Sunarso, dkk. 2008. Pendidikan

Kewarganegaraan PKn untuk Perguruan

Tinggi. Yogyakarta. UNY Press.

Susanto, Ahmad. 2013. Teori Belajar dan Pembelajaran di Sekolah Dasar.

Jakarta: Kencana Prenada Media Group 